\author{
Александр Борисович Бушев \\ Тверской государственный университет \\ iD \\ ORCID https://orcid.org/0000-0002-8730-0078
}

\title{
АНАТОМИЯ ПРОТЕСТА: ФОЛЬКЛОР - САМИЗДАТ - БЛОГЕРСТВО
}

THE ANATOMY OF PROTEST: FOLKLORE - SAMIZDAT - BLOGGING

Studies of protest cannot but remain relevant and topical: the world is full of protesters and protests. The importance of studies of protests in 20th-cetnury Russia is not only historical but also ethical. Protest in literature chiefly manifests itself in the creation of a work that is not censored. An ideal medium for this kind of literary activity is folklore, samizdat and, nowadays, blogging. In his article, Aleksandr Borisovich Bushev discusses contemporary forms of folklore and the contemporary reception of samizdat literature; he also offers reflections on these, with a special focus on education. Bushev refers to works by samizdat writers and pays special attention to the topic of self-censorship on the example of Soviet writers and their attempts to overcome it through "writing for the drawer" (in the hope for a posthumous publication). Bushev examines also the aesthetic form of artworks exposed to censorship and suppression. The majority of the forms of protest, and the accompanying responses of the authorities, are now of historical importance. Nowadays, literary protest manifests itself differently than in the past: today, the medium is the internet, and blogging is the source of alternative discourse, the discourse of counterculture, and minority discourse.

Keywords: folklore, samizdat, blogging, protests, uncensored literature 


\section{ANATOMIA PROTESTU: FOLKLOR - SAMIZDAT - BLOGOWANIE}

Badanie zjawiska protestów jest nadal aktualne, ponieważ świat jest wciąż pełen protestujących. Rozważania na temat protestów w XX-wiecznej Rosji mają już nie tylko znaczenie historyczne, ale i etyczne. Protest w literaturze wyraża się przede wszystkim poprzez stworzenie dzieła nieocenzurowanego. Idealnym medium dla tego rodzaju działalności jest folklor, samizdat, a dzisiaj również i blogowanie. W artykule omówiono współczesne formy folkloru, współczesną recepcję literatury samizdatu i refleksję nad nim, zwłaszcza w obszarze edukacji. Autor odwołuje się do twórczości pisarzy samizdatu. W pracy podjęto również temat autocenzury w odniesieniu do pisarzy radzieckich i próby jej przezwyciężenia dzięki „pisaniu do szuflady” (z nadzieją na pośmiertną publikację). Zwrócono także uwagę na estetyczne formy twórczości artystycznej — podlegającej cenzurze i zakazanej. Większość form protestu oraz reakcji na nie władzy ma obecnie znaczenie historyczne. Dzisiejszy protest przejawia się w literaturze w inny sposób niż kiedyś - środkiem wyrazu stał się internet, a źródłem dyskursu alternatywnego, kontrkultury i kultury mniejszości stało się blogowanie. Słowa klucze: folklor, samizdat, blogowanie, protest, literatura nieocenzurowana

Настоящая статья ${ }^{1}$ посвящена протесту в русской словесности в XX веке и представляет собой попытку его концептуального осмысления. Формы протеста разнообразны. Они актуальны для социологии, теории образования и истории литературы, часть этих форм важна для понимания общественного дискурса сегодня. Автор предлагает понимание протеста в словесности как процесса создания неподцензурного произведения в системе «фольклор - самиздат - блогерство».

Материалом в работе является неподцензурная словесность XX века и историография самиздата. В работе применяются психобиографический, социологический метод качественного анализа, дискурс-анализ текстов, метод создания концепции ${ }^{2}$.

\footnotetext{
${ }^{1}$ Статья является расширенным и дополненным вариантом текста ГУЛАГ самиздат - диссидентство: осмьсление в России и на Западе, опубликованного в журнале «Лингвориторическая парадигма: теоретические и прикладные аспекты» (№ 25-2, 2020).

${ }^{2}$ Концепции самиздата см., например, Ф. Буббайер, Совесть, диссидентство и реформы в Советской России, РОССПЭН, Москва 2010; Е. Михайлик, Не отражается и не отбрасывает тени: «закрытое об-
} 


\section{ФЕНОМЕН «ПРОТЕСТА»}

Феномен протеста не может не привлекать внимание в силу всемирности и пассионарности. Обсуждая данную проблематику, следует помнить, что существуют социальный, культурный, политический протест. В протесте выделяются акторы, действия, пространство, причины. Некоторые авторы говорят о субъектах, материальных носителях, акциях, объектах, результатах протеста ${ }^{3}$. Протест представляет собой политическое поведение социального актора как не соответствующее ожиданиям. Протестовать приходится тем, чьи права и свободы не реализуются правовым и юридическим путем. Политический протест - это проявление негативного отношения к политической системе в целом, к отдельным ее элементам, нормам, ценностям. Основной теорией политического протеста является теория депривации. Играет роль уровень вовлеченности актора в политический процесс. Незначительный протест может проявляться критической оценкой в кулуаpax, на кухне. Выделяют репертуар протеста - эмотивный, конативный (санкционированные и несанкционированные действия), когнитивный (вербальный). Показательно подразделение протеста на конвенциональные формы протеста (со своими характерными допустимыми формами поведения, например, критика) и неконвенциональные формы протеста. Любое сопротивление может быть ненасильственное, мирное или насильственное, вооруженное. Спектр политических действий протеста простирается от абсентеизма до терроризма. Понимание протестной деятельности актуально и для сегодняшней ситуации.

щество и лагерная титература» // «Новое литературное обозрение» 2009, № 6, с. 356-375; Н.В. Тищенко, Свобода и несвобода в пространстве литературных текстов: дискурс-анализ произведений, посвященных ГУЛАГу // «Философия и культура» 2013, № 4, с. 199-509.

${ }^{3}$ А.Б. Бушев, Протестный дискурс: оптика исследования // «Вопросы теории и практики журналистики» 2015, т. 4, № 2, с. 170-182.

RSL.2021.31.03 s. 3 z 33 


\section{ФОЛЬКЛОР: НЕПОДЦЕНЗУРНОСТЬ}

Показательно представление о том, что в устном рассказе, устном разговоре в очереди, анекдоте, слухе могут быть выражены протестные настроения. Это коррелирует с концепцией Михаила Бахтина о свободе и карнавальности народной смеховой культуры.

Наша концепция «фольклор - самиздат - блогерство» обсуждает тексты протеста. В условиях подцензурности народная культура, по Бахтину, остается свободной, приверженной карнавальной критике существующих конвенций. Кулуарный протест, разговоры остаются в культуре на протяжении всего времени. Достойно внимания и неофициальное народное творчество: так называемый интеллигентский фольклор советского периода, феномен байки, политической частушки, анекдота, неофициальной песни. Феномен неподцензурной словесности, существующей, по многим причинам, рядом со словесностью, одобренной к распространению - продолжает привлекать внимание. Так, наряду с неподцензурной литературой лагерной темы, исследуются и произведения с коллективным автором (ставшие новым фольклором): По тундре, по железной дороге.., Ванинский порт и др. Известна книга Песенный больклор ГУЛАГа Майкла и Лидии Джекобсонов ${ }^{4}$, представляющая фольклор каторги - политических и уголовных заключенных.

В обществе существует традиция устного рассказа 5 . Обращаются к устной истории представители разных гуманитарных специальностей - социологи, историки, филологи, психологи, журналисты.

Байки как концентрации смыслов и своеобразный жанр со своими законами интересуют исследователя. Вот, например, рассказывает Алексей Герман:

\footnotetext{
${ }^{4}$ М. Джекобсон, Л. Джекобсон, Песенньй фольклор ГУЛАГа как исторический источник (1917-1939), Современный гуманитарный университет, Москва 1998.

${ }^{5}$ А.Б. Бушев, Техники интервьюирования для гуманитарного знания // «Лингвориторическая парадигма: теоретические и прикладные аспекты» 2019, № 24, с. 98-101.
}

RSL.2021.31.03 s. 4 z 33 
Я все это проходил: нельзя здороваться с Зощенко. С детства. Я помню, как мы жгли чучело Зощенко на костре. Это же все вокруг меня варилось. Помню Шостаковича, опального, который приходил пить «Боржоми» с папой. И как мы стояли в очереди за сыром «Рокфор», который «выбросили» в магазине в Комарово. За нами стоит мужик в кожаном пальто и говорит про сыр: «Как Шостакович - с гнильцой».

Хейфец жил в Комарово в нашей бане, потому что был проштрафившийся. И он с двумя лауреатскими значками выходил из нашей бани. Спрашивали: Кто это? - Дважды лауреат Сталинской премии! На него рассердился Сталин, потому что он снимал Советскую Мордовию и старался, как мог. За ними ездил грузовик с костюмами и галстуками, которые они надевали на всех трактористов. А промышленность он ездил снимать совершенно в другую республику, потому что в Мордовии не было выразительной промышленности. Но Сталин рассердился и сказал: Не такая Мордовия! И Хейфец улетел в нашу баню6

О чем этот текст?! Несомненно, что на фоне определенного содержания в тексте существует смысл, заложенный автором и детектируемый читателем. И этот смысл не совпадает с содержанием, хотя и выстраивается на его основе. Различие смысла и содержания - центральная идея для теории рефлексии - прекрасно прослеживается при наблюдении за собственным пониманием этих и других баек.

\section{САМИЗДАТ}

Феномен самиздата, самсебяиздата возник как преодоление подцензурности, запрета. За последние годы издано несколько антологий самиздата, тамиздата и магнитиздата - общественного явления, объединившего несколько потоков неподцензурной художественной и политической мысли советского периода: это и произведения первой, второй и третьей волны русской эмиграции, интересные нашим соотечественникам, и произведения зарубежной литературы, и религиозная мысль, и политические, и правозащитные произведения,

${ }^{6}$ Пять женщин Алексея Германа. И все - «Ники» // «Аргументы и факты», 26.04.2000, https://aif.ru/archive/1638987 (13.03.2021).

RSL.2021.31.03 s. 5 z 33 
и тексты экологической тематики, и борьба за «истинный марксизм», и социологическая мысль, и «хроника текущих событий», и произведения магнитиздата, и мемуары тех, кто прошел через карательную психиатрию, необоснованные репрессии, обвинения в диссидентстве и антисоветской агитации. Большинство этих произведений сегодня распространяется в нашем обществе свободно: былой самиздат, былой протест никому не страшен. Есть даже и такая мысль: эти антологии - лучший учебник литературы и истории указанного периода ${ }^{7}$.

Художественный и политический опыт самиздата становится предметом научных оценок ${ }^{8}$.

Вторая причина актуальности таких штудий - полное неведение среднего студента в отношении недавней истории. Современный студент с трудом не только называет эти, казалось бы, значимые имена, но и не может себе представить, какое место занимала неформальная (неподцензурная) художественная и политическая коммуникация в советском обществе и какое занимает в обществе сегодняшнем.

Сегодня пока даже среднее поколение исследователей имеет опыт общения с осколками диссидентства и самиздата. Без труда вспоминаю недавние, как кажется, публичные встречи

\footnotetext{
${ }^{7}$ М.Ш. Барбакадзе и др. (ред.), Антология самиздата. Неподиензурная литература в СССР, 1950-1980-е г2. В 3 томах, Международный институт гуманитарно-политических исследований, Москва 2005; А.И. Стрелянный, Г.В. Сапгир, В.С. Бахтин, Н.Г. Ордынский (сост.), Самиздат века, Полифакт, Минск 1997; Д.Я. Северюхин (ред.), Самиздат Ленинграда, 1950-е-1980-е: литературная энииклопедия, Новое литературное обозрение, Москва 2003.

${ }^{8}$ А.В. Блюм, Как это делалось в Ленинграде. Цензура в годы оттепели, застоя и перестройки. 1953-1991, Академический проект, СанктПетербург 2005; Т.М. Горяева, Политическая цензура в СССР. 1917-1991, РОССПЭЭН, Москва 2002; О.А. Русина, Самиздат в СССР: тексты и судьбы, УрФУ, Екатеринбург 2015; Е.Н. Савенко, На пути к свободе слова, ГПНТ, СО РАН, Новосибирск 2008; О.А. Сурикова, Русский самиздат 1960-1980-х годов: Судьба поэзии модернистов и ее традиици. Московские творческие объединения и периодические издания. Автореф. дис. ... канд. филол. наук, МГУ, Москва 2013.
}

RSL.2021.31.03 s. 6 z 33 
с Александром Солженицыным, Петром Струве, Дмитрием Назаровым, Анатолием Кимом, Дмитрием Медведевым, о. Павлом Адельгеймом, впечатления от выступления деятелей диссидентства и карательной психиатрии по перестроечному телевидению, открытие и публикацию вала запрещенной литературы. Рядом работают люди, которые начинали изучать преданную забвению эмигрантскую литературу Серебряного века, Николая Гумилева, Леонида Бородина, лагерную литературу...

Миллионы людей прошли через ГУЛАГ. Страх - основное наследие этой системы ${ }^{9}$. С 1950-х годов существовал самиздат. В 60-80-х гг. в России было движение диссидентов. Именно в ходе обсуждения наследия сталинизма возникло диссидентство, из которого проистекают все современные идеологические течения, все современные партии. Не сидевший, но пострадавший и высланный из страны Александр Галич в своем песенном творчестве представил лагерную тематику, а в своей биографии - тематику диссидентства. Диссидентство - протест против политических преследований ${ }^{10}$. В самиздате - рефлексия сталинизма, тематика обретения прав человека.

\section{ТРАДИЦИЯ САМИЗДАТА КАК НЕПОДЦЕНЗУРНОЙ ЛИТЕРАТУРЫ}

Мы являемся свидетелями публикации многих запрещенных материалов об эмиграции, которые прорывались к читателю в Советском Союзе. Одними из первых книг по теме явились изданный в 60-е годы роман репатрианта Натальи

${ }^{9}$ В.А. Бачинин, Социальная виктимология // «Свободная мысль» 2011, № 12 , с. $175-188$.

${ }^{10}$ В.К. Буковский, И возвращается ветер, Хроника, Нью-Йорк 1978; Г. Померанц (сост.), Вегетарианская эпоха, Пик, Москва 2003; С. Вессье, За вашу и нашу свободу. Диссидентское движение в России, Новое литературное обозрение, Москва 2015; Л.А. Королева, А.А. Королев, Диссидентство в СССР. Историко-правовые аспекты (1950-1980 гг.). Учебное пособие, ИНФРА-М, Москва 2013. 
Ильиной Возвращение, ее мемуары Дороги и судьбы, опубликованные в годы перестройки мемуары Александра Вертинского. В связи с этим вспоминается и вернувшаяся в перестройку на родину девяностолетняя Ирина Одоевцева, сказавшая о себе, что она вернулась глотнуть славы и умереть. Наверное, со временем будут собраны в отдельную книгу имена ученых, писателей, музыкантов, артистов - русских, обогативших Запад. Скажем, что список писателей эмиграции, которыми гордится Россия, хорошо знаком нам ныне: Аркадий Аверченко, Георгий Адамович, Юлий Айхенвальд, Марк Алданов, Александр Амфитеатров, Михаил Арцыбашев, Константин Бальмонт, Нина Берберова, Иван Бунин, Давид Бурлюк, Владимир Вейдле, Гайто Газданов, Зинаида Гиппиус, Валентин Горянский, Роман Гуль, Дон-Аминадо, Борис Зайцев, Александр Куприн, Владимир Набоков, Дмитрий Мережковский, Алексей Ремизов, Борис Поплавский, Тэффи, Владислав Ходасевич, Саша Черный. А взять изданные на родине книги Бориса Зайцева, Марка Алданова, Михаила Осоргина, Владимира Набокова, Гайто Газданова, Георгия Иванова, Нины Берберовой. Столкновения с эмиграцией множественны: это и реабилитированная русская религиозная философия, и патронируемая Солженицыным библиотека воспоминаний представителей эмиграции, и приезд в Россию потомков тех, кто ушел из России и унес ее в своем сердце.

Венчает усилия по освоению наследия эмиграции созданная в Москве Библиотека-фонд «Русское зарубежье» (Дом русского зарубежья имени Александра Солженицына) на Таганке. Тема осмысляется и в перестроечном кинематографе: можно вспомнить семью известных русских эмигрантов Кривошеиных, ставшую прообразом семьи в фильме Восток - Запад. Многочисленны материалы периодической печати о культурном обмене с эмиграцией. Возвратились на родину книги Виктора Некрасова, Андрея Синявского, Льва Копелева, Александра Галича, Владимира Максимова, Василия Аксенова, Георгия Владимова. Русская диаспора - Россия в рассеянии - продолжает влиять на метрополию. В историографиче- 
ском аспекте интересны книги Евгения Челышева, Вячеслава Костикова ${ }^{11}$. Но, как бы трагичны, интересны и поучительны ни были бы отдельные факты, они - вещи частные. А книга Михаила Назарова ставит своей задачей анализ миссии русской эмиграции ${ }^{12}$.

Эта тематика продолжает привлекать интерес. Так, несколько лет назад прошел круглый стол кафедры журналистики Тверского госуниверситета Неподцензурная литература: фольклор - самиздат - блогерство. В 2020 году к теме обращается мемориальный комплекс «Медное» (Тверская область). Четвертому периоду эмигрантов были посвящены в последнее время несколько конференций в Сочинском госуниверситете. Феномен эмиграции обсуждался на международной конференции в Курском госуниверситете. Библиотека Дома русского зарубежья проводит много историографических мероприятий.

Писатели - жертвы необоснованных политических репрессий - представляют собой разнородную группу. Николай Гумилев - жертва репрессивного режима, но не лагерный поэт. Жертв репрессий Осипа Мандельштама, Михаила Кольцова, Бориса Пильняка, Исаака Бабеля навряд ли можно назвать лагерными литераторами. Также неверно это было бы по отношению к литераторам, состоявшимся в 20-30-е годы и оказавшимся в лагерях, сгинувшим в них и выжившим (Даниил Хармс, Николай Заболоцкий, Николай Олейников, Александр Введенский, Иван Пулькин, Павел Васильев, Павел Флоренский, Борис Корнилов, Петр Орешин, Бенедикт Лившиц, Василий Князев, Александр Чаянов, Сергей Клычков, Владимир Кириллов, Владимир Зазубрин, Артем Веселый, Дмитрий Святополк-Мирский, Николай Устрялов, Бруно Ясенский, Анна Баркова, Иван Солоневич, Григорий Гуковский, Иса-

\footnotetext{
${ }^{11}$ Е.П. Челышев, Российская эмиграция: 1920-930-е годы. История и современность, Граф-Пресс, Москва 2002; В.В. Костиков, Не будем проклинать изгнанье... (Пути и судьбы русской эмиграции), Международные отношения, Москва 1994.

${ }^{12}$ М.В. Назаров, Миссия русской эмиграции, Родник, Москва 1994.
} 
ак Нусинов, Тициан Табидзе, Даниил Андреев, Елена Тагер, Наталья Ануфриева, Александр Солодовников, Сергей Бондарин, Иван Катаев и др.). Серия книг «Сталин и писатели» Бенедикта Сарнова и особенно книги о репрессированных писателях Виталия Шенталинского показывают это время ${ }^{13}$. Шенталинский исследовал материал по открывшимся тогда архивам. Все это хорошо изучено, описано, издано. Предметов для исследования и «популяризации» (лучше говорить о памяти) в творчестве 20-50-х годов мало. Значима в связи с практиками памяти работа общества «Мемориал» ${ }^{14}$. Тем более что сегодня невозможно получить личные, семейные воспоминания - опыт жертв и их родственников уже отдален от нас в истории ${ }^{15}$.

Изучается творчество литераторов-мемуаристов - Тамара Петкевич, Олег Волков, Ольга Адамова-Слиозберг, Александр Солженицын, Варлам Шаламов, Семен Виленский, Евгения Гинзбург, Ефросинья Керсновская, Татьяна Лещенко-Сухомлина, Татьяна Окуневская, Лев Разгон, Анатолий Жигулин, Александр Перепеченых, Януш Бардах, Асир Сандлер и Мирон Этлис, Иван Павлов, Ольга Носова, Нина Луговская, авторы книг Доднесь тяготеет, изданных «Мемориалом». Исследуется творчество бежавших узников лагерей таких, как: Георгий Бессонов Двадиать шесть тюрем и побег с Соловков; Татьяна Чернавина Бежавшие от ГПУ, Иван Солоневич Россия в конилагере, Иван Зайцев Соловки, Михаил Никонов-Смородин Красная каторга и др. Другая группа - поэты, которые начали творить в лагере: Геннадий Черепов, Вольт Митрейкин, Леонид Ситко, Яков Хромченко, Геннадий Темин, Микола Руденко. Показательным краеведческим материалом для нас является творчество поэта Валентина 3/К. Это фигура, связывающая

\footnotetext{
${ }^{13}$ В.А. Шенталинский, Рабы свободы. В литературных архивах КГБ, Парус, Москва 1995.

${ }^{14}$ Ю.Ю. Крохин, Души высокая свобода. Вадим Делоне, Аграф, Москва 2001.

15 Сайт Сахаровского центра: https://library.sakharov-center.ru/vse-fondy/ knigi/493/showType.html; сайт Музея истории ГУЛАГа: https:/gmig.ru/ (8.03.2021).
}

RSL.2021.31.03 s. 10 z 33 
жертв необоснованных репрессий сталинизма и политических заключенных периода диссидентства. 1927 года рождения, родом из Лихославля. В 1945 году - студент Института стали и сплавов. Много лет находился в лагерях (1947-1956, $1958-1968,1970,1972-1977,1977-1982)$ и так до самой смерти. Валентин Зэка подвергался принудительному лечению в спецбольницах психиатрического профиля. Первый срок получил за стихи и за отказ от участия в выборах. В архивах Воркутлага обнаружены стихи. Андрей Синявский, знакомый с ним по мордовским лагерям, говорил о поэте так: «Я не знаю другого такого последовательного антисоветчика» ${ }^{16}$. Энтузиастами восстановления имени явились новошахтинцы, А.Я. Истомина, Леонид Бородин, Владимир Осипов, Петр Вайль. Стихи Валентина Зэка проникли в лагерный фольклор. В них - гражданская смелость, метафорика и романтика, ужасы лагерной жизни. Есть и лирика. Есть его сборник Тени на закате - довольно объемный том, представляющий стихи, поэмы, материалы биографии, воспоминания, два письма незнакомому адресату. Существует первая книга Глоток озона. В стихах и материалах книги биографические реалии - из карел, отец-агроном, мать-буфетчица, повесился отец, парализованная мать, брат-певец. В стихах тверские реалии: Волжский мост, Дорошиха, горбольница № 2, Серебряковская Пристань, тюрьма. Стихи изданы в Израиле, в американских журналах, в журналах «Москва», «НЛО», «Литературная Россия», «Книжное обозрение» и др. На творчество Валентина 3/К можно посмотреть не только через призму его художественной ценности, но и свидетельства человеческой стойкости.

Фигуры послесталинского времени (60-80-е годы), связанные с диссидентским движением и неподцензурной литературой: Лариса Богораз, Анатолий Марченко, Петр Григоренко, Андрей Сахаров, Владимир Буковский, Наталья Горбаневская, Ирина Ратушинская, поэты СМОГа, Андрей Синявский, Юлий Даниэль, Вадим Делоне, Александр Есенин-Вольпин,

16 Т. Сазонов, Мученик поэзии, https://www.krestianin.ru/articles/58818muchenik-poezii (12.03.2021).

RSL.2021.31.03 s. 11 z 33 
Юрий Галансков, Александр Гинзбург, Людмила Алексеева, Наум Коржавин, Лев Копелев, Виктор Некрасов, Владимир Максимов, Леонид Бородин, Борис Вайль, Борис Гройс, Аркадий Белинков, Анатолий Кузнецов, Михаил Мейлах и др. Есть мемуары Александра Подрабинека ${ }^{17}$, книга Глеба Морева Дисcuдентьь $^{18}$, книга устных рассказов диссидентов, книги представителей художественного андеграунда. Надежда Мандельштам написала о людях то, что они хотели бы о себе забыть. Диссидентство - это явление, в котором участников было порядка тысячи человек. Общая аудитория - около 20000 человек. Очень разные крылья - и классические либералы, и борцы за истинный марксизм, и за социализм с человеческим лицом, и христианская ветвь. Рефлексия самиздата огромна. Кроме упомянутых антологий, есть книги - свидетельства художественных диссидентов («вторая культура», художественный самиздат). Известны монографии Владимира Козлова, Николая Митрохина, Александра Даниэля. Характерно название книги Григория Свирского: На Лобном месте. Литература нравственного сопротивления. Самиздат исследуется Дмитрием Северюхиным, Вячеславом Долининым, Татьяной Никольской.

Диссидентство - явление столичное. Провинция трудилась. Имущественный, культурный, образовательный статус русской провинции не позволял ей участвовать в диссидентстве. Все же есть фигуры, связанные с Тверью (101 километр). Вячеслав Бахмин родом из Твери, после освобождения в 1984 году работал программистом, осужден за злостное хулиганство. Сергей Ковалев после освобождения работал электриком в местном драмтеатре. Тамара Целикова, Елена Санникова учились на первых двух курсах филфака ТвГУ. Владимир Осипов после освобождения жил в Твери. Он пишет о тверском литераторе Петре Дудочкине, участвовавшем в издании журнала. Борис Хазанов после освобождения закончил ТГМУ,

\footnotetext{
${ }^{17}$ А. Подрабинек, Диссиденты. Между тюрьмой и свободой, АСТ, Москва 2015.

${ }^{18}$ Г. Морев, Диссиденты, АСТ, Москва 2017.
}

RSL.2021.31.03 s. 12 z 33 
работал врачом. Вера Лашкова работала шофером в Дмитровке Калининской области, жила в Калинине. В Нелидове Тверской области поселился художник-нонконформист Лев Снегирев. Диссидентство представляется логическим завершением самиздата, а самиздат - рефлексией сталинизма в советском обществе.

Диссидентство - явление 60-80-х годов. Налицо проблема определения исторических рамок движения, роли движения. Учитывать надо то, как изменилась жизнь на протяжении одного поколения. Реалии сегодняшней жизни - свободная публикация религиозных взглядов, частная собственность, отсутствие господствующей идеологии, права человека, многопартийность, возможности потребления глобальных массмедиа.

\section{ВНУТРЕННИЙ ПРОТЕСТ: САМОЦЕНЗУРА}

Протест может проявляться в создании произведений «в стол». Продемонстрируем, как поле отрицательных оценок подводит сатирическую типизацию на материалах Дневника Юрия Нагибина ${ }^{19}$. Дневник был опубликован посмертно, как только это стало возможным, и вызвал бурю негативных эмоций. Он прекрасно показал ханжество и двоемыслие эпохи, изобилуя прямыми и косвенными оценками деятелей литературной среды в брежневское время:

Наслаждаясь собственной тупостью, лицемерие, снобизм, очковтирательство, показуха, формализм, безразличие к сути работы, умение лить помои, вязкость в мышлении, ошалевшая от вседозволенности, уникум тупости и самоуверенности, копеечного вероломства, ледяного охамления, темная убежденность в кромешных истинах, душевная стиснутость и непроветриваемость, как мощна и всепобедительная мещанская злоба, охраняющая бдительно свои владения... Ленивая, равнодушная ко всему на свете, вздорная... Талдычь без конца одно и то же, рассудку вопреки и правде наперекор. И народ, ослабленный страхом, с бациллой рабства в крови, примет эту ложь за истину, большей частью - искрен-

${ }^{19}$ Ю.М. Нагибин, Дневник, Книжный сад, Москва 1996. 
не... невежественные, неодаренные и малоумные люди... мошеннические проделки... фокусы... несправедливость всех видов... в здоровую основу всего этого поверить было трудно... хамство, ненависть, злоба обрушивались на меня со всех сторон... вранье неквалифицированное, не убедительное, когда человек не работает над своей ложью, а ляпает первое, что приходит в его рассеянную башку... готовность к безудержному, беспардонному вранью... умеющая только разводить трехкопеечную демагогию... ложь и смрад в конец распоясавшейся злобности... страшная мещанка шекспировского масштаба... сплав омерзительного: душнейшего мещанства, лицемерия, ханжества, ненависти и презрения к подчиненным, раболепства перед власть и силу имущими, непросвещенностью, трусостью, страстью к доносам, хамством и злобой. Несмотря на обилие составляющих, это монолит, образец прочности и цельности ${ }^{20}$.

\section{ПРОТЕСТ В ПЛАСТИЧЕСКОМ ИСКУССТВЕ: ДРУГОЕ ИСКУССТВО}

Сатирическая типизация советского социума проявилась в пластических искусствах прежде всего в традиции соц-арта. Необходимо выделить внимание к соц-арту (проекты «Соцарт», «Сообщники», «Русский поп-арт») - в движении от Виталия Комара и Александра Меламида до Александра Виноградова и Владимира Дубосарского. Показателен интерес к гибридному креолизированному тексту художественного произведения (Эрик Булатов со стихами Всеволода Некрасова), исследованию социальной ментальности (Илья Кабаков). Другим направлением, вызывающим рефлексию, является московская абстракция и ее динамика. Одинокий и жалкий абстракционист с горячечными видениями и непомерными социальными амбициями путешествует по альбомам Кабакова, часто мелькает в творчестве Комара и Меламида, Герловиных - Сокова, а затем переходит в работы Альберта, «мухоморов» и «медгерменевтов».

Новые имена творцов искусства последней четверти XX века присутствуют в прекрасной книге Ильи Кабако-

${ }^{20}$ А.Б. Бушев, Жанры и языковые механизмы комического // «Studia Culturae» 2011, № 12, c. 220-221.

RSL.2021.31.03 s. 14 z 33 
ва $^{21}$, в книге Нины Молевой об Элии Белютине, в авторефлексии художников. Показательно внимание и изучение метапоэтики - представлений художников о творчестве самих художественных манифестов. Осмысляется то, что вошло в русское искусство в конце XX и в первое десятилетие XXI века, то, что появилось в галереях (Эрик Булатов, Олег Кулик, Илья Кабаков, Сергей Бугаев-Африка, Ирина Нахова, Александр Виноградов и Владимир Дубосарский, Дмитрий Врубель и Виктория Тимофеева, Айдан Салахова). Осмысляется и то, что уже стало историей (Дмитрий Краснопевцев, Оскар Рабин, Тимур Новиков, Анатолий Зверев). Значимы в понимании творчества художественного авангарда 60-х годов воспоминания Галины Маневич - Цвет прошедшего времени и Опьт благодарения ${ }^{22}$. Автор - жена известного художника Эдуарда Штейнберга, киновед. В фокусе автора - странный художественный феномен - неофициальное советское искусство, осмысленный нами лишь в XXI веке: творческое объединение «Лианозово», в которое входили, среди других, Оскар Рабин, Евгений Кропивницкий, Владимир Немухин, Лидия Мастеркова. Зверев, удостоившийся персональных выставок. Круг Юло Соостера, Илья Кабаков, Владимир Янкилевский. Манеж 1962 года. Михаил Шварцман, Владимир Яковлев, Лев Нусберг. Легендарные одиночки - Эрик Булатов, Дмитрий Краснопевцев, Олег Целков. Сегодня они в музее личных коллекций, в музее современного искусства, в ГЦСИ, в самых лучших галереях, в Гараже, в Третьяковке, по всему миру. Трагическое Беляево 1974 года. Измайлово. ВДНХ. Малая Грузинская. Подполье. Жрецы подполья. Оскар Рабин, Александр Глезер, Михаил Шемякин, Лев Нусберг, Михаил Гробман, Эрнст Неизвестный, Василий Ситников, Виталий Комар, Александр Меламид, Олег Целков и т. д. подались за кордон.

${ }^{21}$ И. Кабаков, 60-70-е.. Записки о неофициальной жизни в Москве, Новое литературное обозрение, Москва 2008.

${ }^{22}$ Г.И. Маневич, Опьт благодарения: Воспоминания, Аграф, Москва 2009; ее же, Цвет прошедшего времени, Аграф, Москва 2010.

RSL.2021.31.03 s. 15 z 33 
Показательно, что в авангарде второй половины XX века вновь происходит обращение к русскому авангарду 20-х годов. Рассматривая позднесоветское искусство России, мы можем выделить творчество официального и неофициального советского искусства. Но процесс был сложнее. Левый МОСХ, горком графиков, выставки на Малой Грузинской, параллельное советское искусство. Неофициальное искусство представлено именами Ильи Кабакова, Олега Васильева, Эрика Булатова, Оскара Рабина, Владимира Немухина, Эдуарда Штейнберга, Юрия Купера, Эдуарда Дробицкого, Константина Худякова. Рядом вполне официальные новаторы Наталья Нестерова, Татьяна Назаренко, Ольга Булгакова, Александр Ситников, Андрей Волков, Елена Романова, Олег Филатчев, фотореалист Семен Файбисович. В неофициальном искусстве шестидесятники - это Лианозовская школа, Анатолий Зверев, Александр Харитонов, Василий Ситников, Владимир Яковлев, Михаил Шварцман, Владимир Вейсберг, Дмитрий Краснопевцев, Олег Васильев, Олег Целков. Критиковались, но не были неофициальными представители сурового стиля - Вейсберг, Никонов, Иванов, Мордовин, Филатчев, Романова, Симаков. Из представителей Малой Грузинской известны Константин Худяков, Вячеслав Калинин, Сергей Симаков, Сергей Шаров. Их творчество заставляет представить знаменитые выставки в подвале кооперативного дома на Малой Грузинской, 28. Люди стояли в очереди по шесть часов, удивляя своим упорством КГБ. Анатолий Зверев, Сергей Шаров, Сергей Симаков, Анатолий Лепин, Ната Конышева, Василий Шевченко - один из ликов андеграунда в эпоху повального соцреализма. Сегодня в экспонирующейся коллекции Симакова - и неэскпонировавшийся сорок лет назад липецкий авангардист Василий Шевченко, и тверской художник Владимир Маслов. Открытие галереи авангарда в Угличе при содействии журнала «Углече Поле» из собрания игумена Рафаила (Симакова) сопровождалось публикацией альбома ${ }^{23}$. Значим рассказ, как заново открывали

${ }^{23}$ И. Смолин (ред.), Авангард с Малой Грузинской. Из коллекизи игумена Рафаила, Зебра Е, Москва 2018.

RSL.2021.31.03 s. 16 z 33 
русский авангард, подчас через западных посредников, как обращались к наследию иконы, книжной миниатюры. Искусство шестидесятников неоднородно. К художникам третьего пути в официальном искусстве обычно относят представителей левого МОСХа - Татьяну Назаренко, Наталью Нестерову, Алексея Ситникова, Ольгу Булгакову, Олега Филатчева, Елену Романову, Татьяну Насипову, Ирину Старженецкую, Николая Смирнова. Лидеры изобразительной метафизики 60-х - Юрий Соболев и Юло Соостер. Поначалу прославились книжной графикой художники Сретенского бульвара - Илья Кабаков, Эрик Булатов, Виктор Пивоваров, Эрнст Неизвестный, Владимир Янкилевский, Анатолий Брусиловский, Юло Соостер.

Последние годы проходит много выставок шестидесятников. Значимым моментом авангардности был отказ от соцреализма, от фигуративности, концептуализм. Имена художников неофициального искусства и новаторов - Алексей Тяпушкин, Евгений Рухин, Михаил Гробман, Дмитрий Плавинский, Владимир Янкилевский, Лидия Мастеркова, Владимир Немухин, Александр Харитонов, Борис Свешников, Евгений Михнов-Войтенко. Владимир Овчинников, Вагрич Бахчанян, Петр Беленок, Виктор Пивоваров, Леонид Соков, Иван Чуйков, Лев Нусберг, Леонид Пинчевский, Владимир Яковлев, Олег Целков, Владимир Котляров, Михаил Рогинский, Анатолий Путилин, Валентин Воробьев, Валентин Самарин, Олег Соханевич, Эдуард Зеленин, Владимир Бугрин, Андрей Абрамов, Игорь Макаревич, Александр Косолапов, Виталий Комар и Александр Меламид, Игорь Захаров-Росс, Борис Штейнберг, Владимир Брайнин, Дмитрий Аникеев, Максим Кантор, Ирина Старженецкая, Леонид Баранов, Борис Пророков, Илларион Голицын. Так, выставка одного из лидеров искусств шестидесятников Дмитрия Плавинского в Твери демонстрировала авангардность целой художественной династии. 


\section{ПРОТЕСТ В ПУБЛИЦИСТИКЕ}

Александр Солженицын предстает перед нами по прошествии времени в разных ипостасях - как историческая фигура (писатель, «который первый и прямо под пастью все это громко вызвездит режиму в лоб» $\left.{ }^{24}\right)$, как прозаик, мемуарист, поэт, драматург, историк (здесь и знаменитая библиотека воспоминаний эмигрантов, и историческая публицистика, и Красное колесо, но, по-моему, яснее всей этой книги с претензиями на Джона Дос Пассоса строки Бориса Пастернака: «Ты из сумерек, социалистка»), политический теоретик, диссидент (инакомыслящий, хотя сам себя таковым не считал), персонаж литературной жизни, литературный критик, публицист, новатор языка. Главной заслугой Солженицына представляется по прошествии времени разоблачение сталинизма. Его произведения стоят в ряду с такими авторами, как Варлам Шаламов, Анна Ахматова. На эту тему существует много книг (Слиозберг, Петкевич, Гинзбург, Волков, Григоренко). Кто-то из категории оппонентов Солженицына сказал: «Меня не убеждает». На это писатель хорошо заметил: «А весь мир убедили» ${ }^{25}$.

Автор снискал разные оценки. Известны отрицательные оценки Владимира Войновича, Владимира Бушина, Варлама Шаламова, Андрея Синявского, восторженная оценка Петра Струве. На наш взгляд, надо оценивать не личность, а тексты. Личность совершала ошибки, давала ошибочные оценки (ошибками в случае Солженицына можно считать позицию по Чечне, Курилам, Власову, оценку кровопролитной войны, переоценку Александра Колчака и Петра Столыпина, портреты которых висели на стене его дома). Показательна критика

\footnotetext{
${ }^{24}$ Цит. по: В. Войнович, Портрет на фоне мифа, https://imwerden.de/pdf/vojnovich_portret_na_fone_mifa.pdf(14.03.2021).

${ }^{25}$ А.Б. Бушев, Публицистика Солженицьна: сбывшиеся пророчества // Л. Трубина (ред.), «Жить не по лжи»: нравственные императивы А.И. Солженицына в современной России и мире. Сборник статей по итогам научно-практической конферениии, Московский педагогический государственный университет, Москва 2019, с. 33-39.
}

RSL.2021.31.03 s. 18 z 33 
справа и слева, и представителями эмиграции, и представителями демократического движения, и коммунистами (многие из этих ярлыков известны: фальсификатор, реакционный утопист, гомерические интеллектуальные претензии, морализм, выросший на базе нигилизма, неутолимая страсть к политическому пророчеству с инфантилизмом, потеря художественного вкуса).

При прочтении публицистики Солженицына (три тома публицистики), полной оценок, ошибок, парадоксальных, неортодоксальных или, наоборот, стандартных взглядов (она представлена и в т. н. имковских изданиях, и на прекрасном сайте Фонда Солженицына ${ }^{26}$, и в собрании сочинений - по периодам в Советском Союзе, на Западе, в России), у нас, как правило, срабатывает стереотип: настоящий писатель есть публицист. Но малозначима публицистика Георгия Маркова, Михаила Алексеева, Сергея Залыгина, Анатолия Иванова, Cемена Бабаевского, Михаила Шолохова. Дело не в идеологии. Отсутствует публицистика у Бориса Пастернака, Владимира Набокова, Анны Ахматовой, Виктора Пелевина. Она может быть заменена художественной эссеистикой. Но у Солженицына есть обширная политическая публицистика, он с юношеских лет интересовался миром политического.

Начнем с самого начала хронологически. В письме к четвертому съезду Союза советских писателей Солженицын обращается по поводу цензуры. Он поднимает вопрос о запрещенных писателях. Иван Бунин, Михаил Булгаков, Андрей Платонов, Осип Мандельштам, Максимилиан Волошин, Николай Гумилев, Николай Клюев, Евгений Замятин, Алексей Ремизов, Анна Ахматова, Сергей Есенин, Борис Пильняк, Федор Достоевский - возвращены читателю. Собственные произведения Солженицына - свободно циркулируют. Михаил Булгаков, Анна Ахматова, Марина Цветаева, Борис Пастернак, Михаил Зощенко, Андрей Платонов, Александр Грин, Василий Гроссман, Борис Васильев, Осип Мандельштам, Артем Веселый, Борис Пильняк, Исаак Бабель, Тициан Табидзе, Нико-

${ }^{26}$ Сайт Фонда Солженицына: http://www.solzhenitsyn.ru/fond/ (12.03.2021). 
лай Заболоцкий сегодня в защите не нуждаются, пережили триумфальное возвращение, вал журнальных публикаций. Далее отметим поминальное слово о Александре Твардовском, известную книгу Бодался теленок с дубом. Несмотря на желание видеть какие-то нюансы взаимоотношений и трений с «Новым миром», книга выглядит по прошествии времени очень корректно. В ней много: клятва воздержания от правды, называемая соцреализмом, потаенность живой неподцензурной литературы, история отечественной публицистики 60-х годов как история прихода собственных произведений к читателю (жанр называется Солженицыным «вторичная литература»). Очень любопытна и относящаяся ко «вторичной литературе» книга Угодило зернышко промеж двух жерновов, показывающая причины, по которым Солженицына приняла первая эмиграция, но не приняла третья. Проекты общественных преобразований Солженицына особенно четко прорисованы в трех публикациях: Письмо вождям Советского Союза, Как нам обустроить Россию, «Русский вопрос» к кониу ХХ века.

\section{ТРАДИЦИЯ ЭМИГРАЦИИ}

Сатирическая традиция третьей и четвертой эмиграции тоже уходит в историю. Эмигранты этих волн - люди очень различные. В рамках краеведческих штудий автор настоящей публикации запросил Интернет о Борисе Хазанове и без труда вышел на его персональный сайт ${ }^{27}$, где есть романы, рассказы и повести, эссе, литературно-критические статьи, переписка автора. Родился в 1928 году в Ленинграде. Кажется, был период жизни семьи на окраинах Империи. Мать-врач, запойное чтение. Затем перед моим взором представала довоенная Москва, самый ее центр. Увлеченность романтиками, дядя-переводчик. После войны - поступление на классическое отделе-

${ }^{27}$ Персональный сайт Бориса Хазанова: http://www.boris-chasanow.imwerden.de (13.03.2021).

RSL.2021.31.03 s. 20 z 33 
ние Московского университета, латынь и греческий. В 1949 году - арест тогда уже студента пятого курса по обвинению в антисоветской агитации. Стоит вчитаться в эти поразительные строки о книге в тюрьме, показывающие ценность феномена литературы в заключении:

Тишина, цоканье сапог. Шествие с надзирателем по галерее вдоль огражденного сеткой лестничного пролета, гуськом, впереди дежурный по камере торжественно несет парашу. Никакой связи с внешним миром, ни радио, ни газет; самое существование застенка окутано тайной. Но зато тюрьма располагала превосходной библиотекой. Непостижимым образом в абсурдном мире следователей, ночных допросов, карцеров, фантастических «дел» и заочных судилищ сохранялись реликты старомодной добросовестности. Раз в две недели в камеру входил библиотекарь. Арестанты могли заказывать книги по своему выбору. Из обширного ассортимента наказаний, какие могло предложить своим обитателям это учреждение, худшим было лишение права пользоваться библиотекой. К счастью, следователи прибегали к нему нечасто. Возможно, они не могли оценить его действенность, так как сами книг не читали. Нетрудно предположить, что в эпоху расцвета тайной полиции, в те послевоенные годы, когда страна испытывала особенно острую нехватку тюремной площади, когда спецкорпус, воздвигнутый еще при наркоме Ежове, был битком набит студентами, врачами, профессорами, евреями и тому подобной публикой, библиотека не могла пожаловаться на недостаток читателей. Бывало так, что заказанного автора не оказывалось на месте. Библиотекарь приносил что-нибудь выбранное наугад им самим. Это могли быть совершенно необыкновенные сочинения, диковинные раритеты, о которых никто никогда не слыхал. Попадались даже, о ужас, произведения врагов народа. Имена, выскобленные из учебников литературы, писатели, одного упоминания о которых было достаточно, чтобы загреметь туда, где обретались мы, и - получить возможность их прочесть. Тюремная библиотека пополнялась за счет литературы, изъятой при обысках и конфискованной у владельцев. Книги отправлялись в узилище следом за теми, кто их написал. Что еще нужно написать бывшим лагерникам (политическим), чтобы навсегда отбить охоту к коммунистическим экспериментам?!28

На 1955 год пришлось возвращение из лагеря, хотя тогда казалось, что это временная передышка. И вот Хазанов реша-

${ }^{28}$ Б. Хазанов, Буквы // «Октябрь» 2001, № 4, https://magazines.gorky.media/ october/2001/4/bukvy.html (10.02.2021). 
ет получить профессию врача. Руководствуется, в том числе, и тем, что врачу на зоне легче выжить. В 1961 году он заканчивает медицинский институт в Калинине. Начинается булгаковская жизнь - и появляется возможность написать и сказать о пережитом:

Я никогда не забывал и не забуду до конца жизни, что я бывший заключенный. Это все равно, что бывший люмпен или граф. Чувство это не покидает меня и сегодня, когда я сижу в моей комнате в Мюнхене, в белый февральский день, и пишу эту литературную автобиографию. Можно быть кем угодно: служить в банке, сочинять романы или развозить по домам глаженое белье - и при этом ни на минуту не забывать, что ты граф. Лагерь есть принадлежность к особому сословию. Лагерь есть особого рода расовая принадлежность. Или профессия, которую можно слегка подзабыть. Но разучиться ей нельзя, она остается с тобой навсегда. Лагерь был нашим истинным отечеством, вся же прочая жизнь представлялась поездкой в теплые края, отпуском, затянувшимся оттого, что всесильные учреждения перегружены делами и до тебя просто еще не дошли руки ${ }^{29}$.

Эта цитата показательна в демонстрации того, насколько лагерный опыт не отпускает человека.

Литература вновь появляется в жизни Геннадия Файбусовича (Бориса Хазанова). А затем была новая жизнь: занятия литературой после пятнадцатилетней врачебной практики, работа в журнале «Химия и жизнь». И возможность писать. В эти же годы писатель знакомится с интеллектуальной, думающей Россией: Бенедикт Сарнов, Григорий Померанц, отец Сергий Желудков - история отечественной общественной мысли. Он вспоминал, что несколько новых знакомств с Евгением Барабановым, с Сергеем Желудковым, с Юлием Шрейдером, Григорием Померанцем и профессором Василием Налимовым - приобщили его к другой части полуподпольного диссидентского мира, не ориентированной на отъезд из страны и проявлявшей большой интерес к религиозности,

${ }^{29} Э$. Финкельштейн, Только пепел знает. Интервью, эссе, очерки, Im Werden Verlag, Мюнхен 2014, с. 14, https://imwerden.de/pdf/finkelstein_tolko_pepel_ znaet_2014.pdf (27.02.2021).

RSL.2021.31.03 s. 22 z 33 
христианству, отчасти христианской гностике. Позади - защита кандидатской диссертации, авторство двух книжек научно-популярной прозы, перевод писем Готфрида Лейбница, впереди, уже совсем скоро - угроза второго ареста и отъезд в Мюнхен. Об этом писатель скажет: «Моя жизнь была перерублена трижды: первый раз, когда началась война, второй, когда я был арестован, и третий раз, когда пришлось эмигрировать. Как бы то ни было, началась моя вторая литературная жизнь - в Западной Европе» ${ }^{30}$.

Сегодня иногда в полемическом задоре какой-нибудь собеседник нет-нет, да и спрашивает постаревшего писателя, почему он не едет в сегодняшнюю Россию:

Вероятно, я мог бы привести дюжину доводов. Нужны ли они? Ведь все так просто. Мне там негде и не на что жить. Согласившись выпустить нас на волю, государство ограбило нас дочиста. Все, что я сделал, все следы моего пребывания в России выскоблены. Я лишен пенсии, хоть и работал в Советском Союзе всю жизнь. Лора лежит в Мюнхене на Восточном кладбище. Куда я от нее поеду? Меня в Москве может остановить на улице любой милиционер. Мое пухлое дело хранится в архивах тайной полиции, дожидаясь своего часа. Вы скажете: времена изменились ${ }^{31}$.

Дальнейшее развитие художественной литературы связано в представлении Хазанова с массовым обществом:

Как ни удивительно, до сих пор находятся охотники сочинять романы и слагать стихи. Что бы ни случилось, художественная литература не умирает. Многие убеждены, что будущее за интернетом. Перечисляются неоспоримые преимущества электроники - это прежде всего небывалая оперативность и безграничный демократизм. Могущество новых средств массовой информации - одновременно и следствие, и условие становления нового, никогда прежде не существовавшего общества. Массовое общество сложилось в передовых странах во второй половине прошлого

${ }^{30}$ Б. Хазанов, Литературныц музей. Из дневника писателя // «Октябрь» 2004, № 10, https://magazines.gorky.media/october/2004/10/literaturnyjmuzej.html (28.02.2021).

${ }^{31}$ Его же, Родники и камни, ImWerden Verlag, Мюнхен 2008, с. 7, https:// imwerden.de/pdf/khazanov_rodniki_i_kamni.pdf (2.03.2021).

RSL.2021.31.03 s. 23 z 33 
века и ныне в мучительно-лихорадочном темпе, круша и ломая все, что ему перечит, нарождается в России ${ }^{32}$.

На примере Хазанова мы видим четко артикулированные представления о ненужности опыта писателя современной четвертой эмиграции читателям в России. Случай Хазанова пример типичности генезиса писателя четвертой эмиграции (лагерный опыт, диссидентство, духовные поиски, роль классики). Показательны размышления автора о культуре и языке современной России и даже не диаспоры, а Атлантиды, к которой принадлежит автор.

\section{БЛОГЕРСТВО}

Протесты в фольклоре и самиздате ушли в прошлое. Учитывать надо то, как изменилась жизнь на протяжении одного поколения. Реалии сегодняшней жизни - свободная публикация религиозных взглядов, частная собственность, отсутствие господствующей идеологии, права человека, многопартийность, возможности потребления глобальных массмедиа.

Идея авторской концепции - не сколько трактовать отдельные произведения, выходившие в самиздате, как бы ни были велики и интересны они и их авторы, а попытаться понять, как во временных рамках 1918-1994 гг. функционировал этот альтернативный дискурс, дать оценку его исторической роли, показать его преемников (Интернет?).

Это особенно интересно и важно сделать именно сегодня, когда живы люди, читавшие и писавшие самиздат, распространявшие неофициальные фольклорные тексты. Показательно, что эти люди перешли сегодня в Интернет, на ведение блогов. Отдельная проблема посвящена фигуре блогера. Блогер - это сегодняшний самиздатчик?

В последние годы предметом внимания в научных исследованиях журналистики становится блогерство - новый

${ }^{32}$ Его же, Ров и за́мок. К открытому письму А.Г. Машевского, http:// folioverso.ru/misly/2009_9/hazanov_rov.htm (4.03.2021).

RSL.2021.31.03 s. 24 z 33 
феномен неподцензурной коммуникации, снимающий противопоставление автора и читателя в сетевой журналистике, меняющий функцию современного журналиста, требующий особой фактуры речи. Меняется в Сети и функция журналиста: современный журналист становится модератором авторского контента сотен гражданских журналистов.

Отметим, что сегодняшнее понятие «журналистика» размывается и становится все более нечетким. Нельзя сказать, что и прежде все было ясно определено и нормировано речь идет о гуманитарных сферах, где много субъективного. Развитие цифровой среды - это ключевая причина ускорения процессов распада прежних систем и трансформация элементов в новые формы связей и отношений. Журналистами зачастую называют разных участников массовых социальных коммуникаций: пиар-специалистов, пропагандистов, копирайтеров, авторов и редакторов корпоративных текстов.

При этом теряется ключевая сущность понятия - ее гражданская составляющая. Журналистика - это деятельность на благо для людей в обществе и для граждан страны, как бы банально это ни звучало. Исследователь Иосиф Дзялошинский, например, выделяет три основных вектора отношения журналистики к аудитории: влияния (журналистика управления), информирования (рыночная журналистика) и соучастия (гражданская журналистика) ${ }^{33}$. Понятно, что нет чистых образцов и чаще всего присутствуют смешанные формы. Но здесь принципиально именно гуманитарное отношение журналист-аудитория. В первых двух случаях журналист отчужден от аудитории и воспринимает ее объектом воздействия. В третьем случае журналист и аудитория - равноправные субъекты взаимоотношений. Не является ли журналистика «влияния», скорее, работой в поле пропаганды? Неважно чего и какой - государственной, корпоративной или пропаганды здорового образа жизни. А во втором случае, чем

${ }^{33}$ И.М. Дзялошинский, Журналистика соучастия. Как сделать СМИ полезньми людям, Престиж, Москва 2006.

RSL.2021.31.03 s. 25 z 33 
рыночная журналистика отличается от практики продаж товаров и услуг? И если целью работы редакции является только прибыль, то какое отношение такая деятельность имеет к общественным интересам и, следовательно, журналистике? В действительности журналистикой является только тот вид деятельности, который связан с общественным интересом, с ценностями гражданского общества. Это вовлеченная в интересы общества работа с информацией. Остальное различные формы работы с информацией в сфере массовых коммуникаций ${ }^{34}$.

Изучение особенностей коммуникации в Интернете предпринято нами в 2020 году. Оказалось, что комментарии обладают выраженной спецификой. Какова же эта специфика? При самом беглом взгляде понятно, что там много сокращений, неграмотности, непонятно случайной или специальной. Комменты ироничны и даже токсичны, агрессивны. Они содержат вербальную агрессию, инвективы, иронию, языковую игру. По лексике - это субстандарт, сленг, жаргон, даже вульгаризмы. Они полны оценочности, субъективности. Они указывают на уровень подготовки и уровень дискуссии аудитории.

Стиль электронного текста своеобразен и отличается от стиля печатного текста. Даже в простейших текстах мы уже видим средства языковой экономии в SMS-сообщениях. Показательными характеристиками таких текстов являются краткость, ожидание незамедлительного ответа, неформальный характер сообщений, пренебрежение ошибками и допущение творчества в способах сокращения информации.

Уже при первых исследованиях общения в сети высказывались наблюдения над характером коммуникации в ней (ироничность, агрессивность, аддикция, безграничные игровые возможности при анонимности масок и т. д.) Это общение лично-публичного характера, для которого характерны ано-

\footnotetext{
${ }^{34}$ См. подробнее: М. Корнев, Как изменилось понятие «журналистика» в современном иифровом пространстве? // MediaToolbox.ru, http:// mediatoolbox.ru/blog/kak-izmenilos-ponyatie-zhurnalistika-v-sovremennomtsifrovom-prostranstve/ (13.03.2021).
}

RSL.2021.31.03 s. 26 z 33 
нимность, безнаказанность, карнавализация, бесчисленные легкие возможности самопрезентации.

\section{КОНТРКУЛЬТУРА ПРИШЛА В ИНТЕРНЕТ!}

Недавно автор настоящей статьи внимательно и досконально читал книгу Шизореволющия Андрея Хлобыстина, ставшую лауреатом премии Кандинского. Это очерки ленинградской культуры второй половины XX века. Тимур Новиков, Георгий Гурьянов, Владислав Мамышев-Монро и др., уже переместившиеся в мир иной. Книга современника и соучастника художественной жизни Ленинграда 70-90-х годов. Книгу позволил скачать авторский блог. Считаю, что книга удалась, потому что ее писал участник художественной жизни, задокументировавший эту жизнь, современник. Многое задокументировал автор: начинается от поколения, которое начисто отвергло советский официоз и оппозиционную ему культуру, как появились русский рок, ЛСД, ленинградская богема, некрореалисты, знаменитый ноль, акционизм и соскальзывание в масскульт, в медиагламур и пошло-повсеместный пиарт. Работа заканчивается концептуальными рассуждениями о путях искусства.

Примета времени - несколько лекций Хлобыстина и выступления его героев можно прослушать на YouTube ${ }^{35}$. Лекции

\footnotetext{
${ }^{35} \mathrm{https} / / /$ www.youtube.com/watch?v=xvYluOxdnjo, https://www.youtube.com/watch?v=KSH4fuvkZOI https://www.youtube.com/watch?v=PkIzl0uba70, https://www.youtube.com/watch?v=SwOHNu9pLlU, https://www.youtube.com/watch?v=BmCoAp2JAwA,

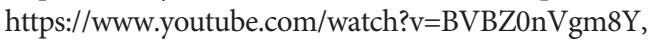
https://www.youtube.com/watch?v=OLphBGdrHFQ, https://www.youtube.com/watch?v=sBMooLNVOVY, https://www.youtube.com/watch?v=Q-sTz3GXz7w, https://www.youtube.com/watch?v=gXFCDW9meeU, https://www.youtube.com/watch?v=-cq2H20PXHY, https://www.youtube.com/watch?v=kZr8YRBRzYc, https://www.youtube.com/watch?v=d93fUWQ2gdk, https://www.youtube.com/watch?v=FtnJ-HjNHrE, https://www.youtube.com/watch?v=HVzg5ub8In8 (3.03.2021).
} 
ограничены временем и не идут ни в какое сравнение с книгой. Но мы видим, что новые медиа пока дополняют старые, а там как знать...

\section{Выводы}

Протест в словесности проявляется прежде всего в создании неподцензурного произведения. Прекрасной средой для этого является фольклор, самиздат, а сегодня блогерство. Большинство форм протеста и реакция властей на него имеют историческое значение. Сегодняшний протест проявляется в словесности иначе, чем прежде: фольклор, неподцензурность имеют среду для выражения - Интернет. Альтернативный дискурс и дискурс контркультуры и миноритарной культуры имеют современный субстрат в виде блогерства.

\section{REFERENCES}

Antologiya samizdata. Nepodcenzurnaya literatura v SSSR, 1950-1980-e gg. V 3 tomakh. Ed. Barbakadze, Mark Sh., et al. Moskva: Mezhdunarodnyy instytut gumanitarno-politicheskikh issledovaniy, 2005 [Антология самиздата. Неподиензурная литература в СССР, 1950-1980-е гг. В 3 томах. Ред. Барбакадзе, Марк Ш. и др. Москва: Международный институт гуманитарнополитических исследований, 2005].

Avangard s Maloy Gruzinskoy. Iz kollektsii igumena Rafaila. Ed. Smolin, Igor'. Moskva: Zebra E, 2018 [Авангард с Малой Грузинской. Из коллекиии игумена Рабаила. Ред. Смолин, Игорь. Москва: Зебра Е, 2018].

Bachinin, Vladislav A. "Social'naya viktimologiya." Svobodnaya mysl', no. 12, 2011: 175-188 [Бачинин, Владислав А. “Социальная виктимология.” Свободная мысль, № 12, 2011: 175-188].

Blyum, Arlen V. Kak eto delalos'v Leningrade. Tsenzura v gody ottepeli, zastoya i perestroyki. 1953-1991. Sankt-Peterburg: Akademicheskiy proyekt, 2005 [Блюм, Арлен В. Как это делалось в Ленинграде. Цензура в годы оттепели, застоя и перестройки. 1953-1991. Санкт-Петербург: Академический проект, 2005].

Bubbayyer, Filip. Sovest', dissidentstvo i reformy v Sovetskoy Rossii. Moskva: ROSSPEN, 2010 [Буббайер, Филип. Совесть, диссидентство и ребормы в Советской России. Москва: РОССПЭН, 2010]. 
Bukovskiy, Vladimir K. I vozvrashchaetsya veter. N’yu-York: Khronika, 1978 [Буковский, Владимир К. И возвращзается ветер. Нью-Йорк: Хроника, 1978].

Bushev, Aleksandr B. "Art-konsalting: sostavlyayushchiye kommunikativnoy kompetentsii." Strategicheskiye kommunikatsii $v$ sovremennom mire: sbornik materialov po rezul'tatam nauchno-prakticheskikh konferentsiy, Saratov, 30 oktyabrya 2019 goda - 22 oktyabrya 2020 goda. Ed. Golub, Ol'ga Yu. 27-32. Saratov: Izdatel'stvo "Saratovskiy istochnik," 2020 [Бушев, Александр Б. "Арт-консалтинг: составляющие коммуникативной компетенции." Стратегические коммуникации в современном мире: сборник материалов по результатам научно-практических конферениий, Саратов, 30 октября 2019 года - 22 октября 2020 года. Ред. Голуб, Ольга Ю. 27-32. Саратов: Издательство “Саратовский источник,” 2020].

Bushev, Aleksandr B. "Chetvertaya emigratsiya: sluchay Borisa Khazanova." Lingvoritoricheskaya paradigma: teoreticheskiye i prikladnyye aspekty, no. 221, 2017: 203-207 [Бушев, Александр Б. “Четвертая эмиграция: случай Бориса Хазанова." Лингвориторическая парадигма: теоретические и прикладные аспекты, № 22-1, 2017: 203-207].

Bushev, Aleksandr B. "GULAG — samizdat - dissidentstvo: osmysleniye v Rossii i na Zapade." Lingvoritoricheskaya paradigma: teoreticheskiye i prikladnyye aspekty, no. 25-2, 2020: 64-66 [Бушев, Александр В. “ГУЛАГ - самиздат диссидентство: осмысление в России и на Западе.” Лингвориторическая парадигма: теоретические и прикладные аспекты, № 25-2, 2020: 64-66].

Bushev, Aleksandr B. "Khudozhestvennyye stili plasticheskogo iskusstva XX veka i khudozhestvennyy yazyk." Diskurs sovremennykh mass-media v perspektive teorii, sotsial'noy praktiki i obrazovaniya: sbornik trudov Mezhdunarodnoy nauchno-prakticheskoy konferentsii, Belgorod, 8-9 oktyabrya 2020 goda. Ed. Kozhemyakin, Yevgeniy A., Kryukova, Svetlana V., Beloyedova, Anna V. 11-15. Belgorod: Belgorodskiy gosudarstvennyy natsional'nyy issledovatel'skiy universitet, 2020 [Бушев, Александр Б. "Художественные стили пластического искусства ХХ века и художественный язык.” Дискурс современных масс-медиа в перспективе теории, соииальной практики и образования: сборник трудов Международной научно-практической конферениии, Белгород, 8-9 октября 2020 года. Ред. Кожемякин, Евгений А., Крюкова, Светлана В., Белоедова, Анна В. 11-15. Белгород: Белгородский государственный национальный исследовательский университет, 2020].

Bushev, Aleksandr B. "Protestnyy diskurs: optika issledovaniya." Voprosy teorii i praktiki zhurnalistiki, vol. 4, no. 2, 2015: 170-182 [Бушев, Александр Б. “Протестный дискурс: оптика исследования.” Вопросы теории и практики журналистики, т. 4, № 2, 2015: 170-182].

Bushev, Aleksandr B. "Publicistika Solzhenicyna: sbyvshiesya prorochestva." "Zhit' ne po lzhi:" nravstvennye imperativy A.I. Solzhenicyna v sovremennoy Rossii i mire. Sbornik statey po itogam nauchno-prakticheskoy konferentsii. Ed. Trubina, Lyudmila A. 33-39. Moskva: Moskovskiy pedagogicheskiy gosudarstvennyy universitet, 2019 [Бушев, Александр Б. “Публицистика Солженицына: сбывшиеся пророчества." “Жить не по лжи:” нравственные императи-

RSL.2021.31.03 s. 29 z 33 
вы А.И. Солженицына в современной России и мире. Сборник статей по итогам научно-практической конференции. Ред. Трубина, Людмила А. 33-39. Москва: Московский педагогический государственный университет, 2019].

Bushev, Aleksandr B. “Tekhniki interv'yuirovaniya dlya gumanitarnogo znaniya.” Lingvoritoricheskaya paradigma: teoreticheskie i prikladnye aspekty, no. 24, 2019: 98-101 [Бушев, Александр Б. “Техники интервьюирования для гуманитарного знания.” Лингвориторическая парадигма: теоретические и прикладные аспекты, № 24, 2019: 98-101].

Bushev, Aleksandr B. "Yazykovaya lichnost' blogera." Rodnaya slovesnost' v sovremennom kul'turnom i obrazovatel'nom prostranstve. Ed. Milyugina, Yelena G. 71-76. Tver': Tverskoy gosudarstvennyy universitet, 2021 [Бушев, Александр Б. “Языковая личность блогера." Родная словесность в современном культурном и образовательном пространстве. Ред. Милюгина, Елена Г. 71-76. Тверь: Тверской государственный университет, 2021].

Bushev, Aleksandr B. "Zhanry i yazykovyye mekhanizmy komicheskogo." Studia Culturae, no. 12, 2011: 220-221 [Бушев, Александр Б. “Жанры и языковые механизмы комического.” Studia Culturae, № 12, 2011: 220-221].

Chelyshev, Yevgeniy P. Rossiyskaya emigratsiya: 1920-1930-e gody. Istoriya i sovremennost'. Moskva: Graf-Press, 2002 [Челышев, Евгений П. Российская эмиграция: 1920-1930-е годы. История и современность. Москва: ГрафПресс, 2002].

Dzhekobson, Maykl, Dzhekobson, Lidiya. Pesennyy fol'klor GULAGa kak istoricheskiy istochnik (1917-1939). Moskva: Sovremennyy gumanitarnyy universitet, 1998 [Джекобсон Майкл, Джекобсон, Лидия. Песенный фольклор ГУЛАГа как исторический источник (1917-1939). Москва: Современный гуманитарный университет, 1998].

Dzyaloshinskiy, Iosif M., Zhurnalistika souchastiya. Kak sdelat' SMI poleznymi lyudyam. Moskva: Prestizh, 2006 [Дзялошинский, Иосиф М., Журналистика соучастия. Как сделать СМИ полезными людям. Москва: Престиж, 2006].

Finkel'shteyn, Eytan. Tol'ko pepel znayet. Interv'yu, esse, ocherki. Myunkhen: ImWerden Verlag, 2014, https://imwerden.de/pdf/finkelstein_tolko_pepel_ znaet_2014.pdf. Accessed 27 February 2021 [Финкельштейн, Эйтан. Только пепел знает. Интервью, эссе, очерки. Мюнхен: ImWerden Verlag, 2014, https://imwerden.de/pdf/finkelstein_tolko_pepel_znaet_2014.pdf. Дата обращения: 27 февраля 2021].

Goryaeva, Tat'yana M. Politicheskaya cenzura v SSSR. 1917-1991. Moskva: ROSSPEEN, 2002 [Горяева, Татьяна М. Политическая цензура в СССР. 1917-1991. Москва: РОССПЭЭН, 2002].

Kabakov, Il'ya. 60-70-ye... Zapiski o neofitsial'noy zhizni v Moskve. Moskva: Novoye literaturnoye obozreniye, 2008 [Кабаков, Илья. 60-70-е... Записки о неофициальной жизни в Москве. Москва: Новое литературное обозрение, 2008].

Khazanov, Boris. “Bukvy.” Oktyabr', no. 4, 2001, https://magazines.gorky.media/october/2001/4/bukvy.html. Accessed 10 February 2021 [Хазанов, Борис. “Бук-

RSL.2021.31.03 s. 30 z 33 
вы.” Октябрь, №4, 2001, https://magazines.gorky.media/october/2001/4/ bukvy.html. Дата обращения: 10 февраля 2021].

Khazanov, Boris. "Literaturnyy muzey. Iz dnevnika pisatelya." Oktyabr', no. 10, 2004, https://magazines.gorky.media/october/2004/10/literaturnyj-muzej. html. Accessed 28 February 2021 [Хазанов, Борис. "Литературный музей. Из дневника писателя.” Октябрь, № 10, 2004, https://magazines.gorky. media/october/2004/10/literaturnyj-muzej.html. Дата обращения: 28 февраля 2021].

Khazanov, Boris. Rodniki i kamni. Myunkhen: ImWerden Verlag, 2008, https://imwerden.de/pdf/khazanov_rodniki_i_kamni.pdf. Accessed 2 March 2021 [Xaзанов, Борис. Родники и камни. Мюнхен: ImWerden Verlag, 2008, https:// imwerden.de/pdf/khazanov_rodniki_i_kamni.pdf. Дата обращения: 2 марта 2021].

Khazanov, Boris. Rov i zámok. K otkrytomu pis'mu A.G. Mashevskogo, http://folioverso.ru/misly/2009_9/hazanov_rov.htm. Accessed 4 March 2021 [Хазанов, Борис. Ров и за́мок. К открытому письму А.Г. Машевского, httр:// folioverso.ru/misly/2009_9/hazanov_rov.htm. Дата обращения: 4 марта 2021].

Kornev, Maksim. “Kak izmenilos' ponyatiye 'zhurnalistika' v sovremennom tsifrovom prostranstve?" MediaToolbox.ru, http://mediatoolbox.ru/blog/kakizmenilos-ponyatie-zhurnalistika-v-sovremennom-tsifrovom-prostranstve. Accessed 13 March 2021 [Корнев, Максим. "Как изменилось понятие 'журналистика' в современном цифровом пространстве?” MediaToolbox. ru, http://mediatoolbox.ru/blog/kak-izmenilos-ponyatie-zhurnalistika-vsovremennom-tsifrovom-prostranstve. Дата обращения: 15 марта 2021].

Koroleva, Larisa A., Korolev, Aleksey A. Dissidentstvo v SSSR. Istoriko-pravovye aspekty (1950-1980 gg.). Uchebnoye posobiye. Moskva: INFRA-M, 2013 [Королева, Лариса А., Королев, Алексей А. Диссидентство в СССР. Историко-правовые аспекты (1950-1980 г2.). Учебное пособие. Москва: ИНФРА-М, 2013].

Kostikov, Vyacheslav V. Ne budem proklinat' izgnan'ye... (Puti i sud'by russkoy emigratsii). Moskva: Mezhdunarodnye otnosheniya, 1994 [Костиков, Вячеслав В. Не будем проклинать изгнанье... (Пути и судьбы русской эмиграции). Москва: Международные отношения, 1994].

Krohin, Yuriy Y. Dushi vysokaya svoboda. Vadim Delone. Moskva: Agraf, 2001 [Крохин, Юрий Ю. Души высокая свобода. Вадим Делоне. Москва: Аграф, 2001].

Manevich, Galina I. Cvet proshedshego vremeni. Moskva: Agraf, 2010 [Маневич, Галина И. Цвет прошедшего времени. Москва: Аграф, 2010].

Manevich, Galina I. Opyt blagodareniya: Vospominaniya. Moskva: Agraf, 2009 [Маневич, Галина И. Опьт благодарения: Воспоминания. Москва: Аграф, 2009].

Mikhaylik, Yelena. "Ne otrazhaetsya i ne otbrasyvaet teni: 'zakrytoe obshchestvo i lagernaya literatura.” Novoye literaturnoe obozreniye, no. 6, 2009: 356-375 [Михайлик, Елена. “Не отражается и не отбрасывает тени: 'закрытое 
общество и лагерная литература"' Новое литературное обозрение, № 6, 2009: 356-375].

Morev, Gleb. Dissidenty. Moskva: AST, 2017 [Морев, Глеб. Диссиденты. Москва: ACT, 2017].

Nagibin, Yuriy M. Dnevnik. Moskva: Knizhnyy sad, 1996 [Нагибин, Юрий М. Дневник. Москва: Книжный сад, 1996].

Nazarov, Mikhail V. Missiya russkoy emigratsii. Moskva: Rodnik, 1994 [Назаров, Михаил В. Миссия русской эмиграции. Москва: Родник, 1994].

Personal'nyy sayt Borisa Khazanova, www.boris-chasanow.imwerden.de. Accessed 13 March 2021 [Персональный сайт Бориса Хазанова, www.borischasanow.imwerden.de. Дата обращения: 13 марта 2021].

Podrabinek, Aleksandr. Dissidenty. Mezhdu tyur'moy i svobodoy. Moskva: AST, 2015 [Подрабинек, Александр. Диссиденть. Между тюрьмой и свободой. Москва: АCT, 2015].

"Pyat' zhenshchin Alekseya Germana. I vse - 'Niki"' Argumenty i fakty, 26 April 2000, https://aif.ru/archive/1638987. Accessed 13 March 2021 ["Пять женщин Алексея Германа. И все - 'Ники”' Аргументы и бакты, 26 апреля 2000, https://aif.ru/archive/1638987. Дата обращения: 13 марта 2021].

Rusina, Yuliya A. Samizdat v SSSR: teksty i sud'by. Ekaterinburg: UrFU, 2015 [Русина, Юлия А. Самиздат в СССР: тексты и судьбы. Екатеринбург: УрФУ, 2015]. Samizdat Leningrada, 1950-e-1980-e: literaturnaya enciklopediya. Ed. Severyuhin, Dmitriy Y. Moskva: Novoe literaturnoe obozrenie, 2003 [Самиздат Ленинграда, 1950-е-1980-е: титературная энизклопедия. Ред. Северюхин, Дмитрий Я. Москва: Новое литературное обозрение, 2003].

Samizdat veka. Ed. Strelyannyy, Anatoliy I., Sapgir, Genrikh V., Bakhtin Vladimir S., Ordynskiy, Nikita G. Minsk: Polifakt, 1997 [Самиздат века. Сост. Стрелянный, Анатолий И., Сапгир, Генрих В., Бахтин, Владимир С., Ордынский, Никита Г. Минск: Полифакт, 1997].

Savenko, Yelena N. Na puti $k$ svobode slova. Ocherki istorii samizdata. Novosibirsk: GPNT SO RAN, 2008 [Савенко, Елена Н. На пути к свободе слова. Очерки истории самиздата. Новосибирск: ГПНТ СО РАН, 2008].

Sayt Fonda Solzhenitsyna, http://www.solzhenitsyn.ru/fond/. Accessed 12 March 2021 [Сайт Фонда Солженицына, http://www.solzhenitsyn.ru/fond/. Дата обращения: 12 марта 2021].

Sayt Muzeya istorii GULAGa, https://gmig.ru/. Accessed 8 March 2021 [Сайт Музея истории ГУЛАГа, https://gmig.ru/. Дата обращения: 8 марта 2021].

Sayt Sakharovskogo tsentra, https://library.sakharov-center.ru/vse-fondy/knigi/493/showType.html. Accessed 8 March 2021 [Сайт Сахаровского центра, https://library.sakharov-center.ru/vse-fondy/knigi/493/showType.html. Дата обращения: 8 марта 2021].

Sazonov, Timur. "Muchenik poezii." https://www.krestianin.ru/articles/58818muchenik-poezii. Accessed 12 March 2021 [Сазонов, Тимур. "Мученик поэзии.” https://www.krestianin.ru/articles/58818-muchenik-poezii. Дата обращения: 12 марта 2021].

Shentalinskiy, Vitaliy A. Raby svobody. V literaturnykh arhivah KGB. Moskva: Pa-

RSL.2021.31.03 s. 32 z 33 
rus, 1995 [Шенталинский, Виталий А. Рабъ свободь. В литературных arkhivakh КГБ. Москва: Парус, 1995].

Surikova, Ol'ga A. Russkiy samizdat 1960-1980-kh godov: Sud'ba poezii modernistov $i$ yeye traditsii. Moskovskiye tvorcheskiye ob"yedineniya $i$ periodicheskiye izdaniya. Avtoref. diss. ... kand. filol. nauk. Moskva: MGU, 2013 [Сурикова, Ольга А. Русский самиздат 1960-1980-х годов: Судьба поэзии модернистов и ее традииии. Московские творческие объединения и периодические издания. Автореф. дисс. ... канд. филол. наук. Москва: МГУ, 2013].

Tishchenko, Natal'ya V. "Svoboda i nesvoboda v prostranstve literaturnykh tekstov: diskurs-analiz proizvedeniy, posvyashchennykh GULAGu." Filosofiya i kul'tura, no. 4, 2013: 199-509 [Тищенко, Наталья В. “Свобода и несвобода в пространстве литературных текстов: дискурс-анализ произведений, посвященных ГУЛАГу." Философия и культура, № 4, 2013: 199-509].

Vegetarianskaya epokha. Ed. Pomerants, Grigoriy. Moskva: Pik, 2003 [Bezemapuанская эпоха. Сост. Померанц, Григорий. Москва: Пик, 2003].

Vess'ye, Sesil'. Za vashu i nashu svobodu. Dissidentskoye dvizheniye v Rossii. Moskva: Novoye literaturnoye obozreniye, 2015 [Вессье, Сесиль. За вашу и нашу свободу. Диссидентское движение в России. Москва: Новое литературное обозрение, 2015].

Voynovich, Vladimir. "Portret na fone mifa." https://imwerden.de/pdf/vojnovich_ portret_na_fone_mifa.pdf. Accessed 14 March 2021 [Войнович, Владимир. “Портрет на фоне мифа." https://imwerden.de/pdf/vojnovich_portret_na_ fone_mifa.pdf. Дата обращения: 14 марта 2021]. 